\title{
THE WOODLOT IN ONTARIO
}

\section{BY I. C. MARRITT ${ }^{1}$}

According to the 1940 Census, there is slightly over two and one-half million acres ( 4000 square miles) of woodland in the forty-two counties of Southern Ontario. This is 14.1 per cent of the total area in these counties. The percentage varies from 4.4 in Essex to 39.5 in Renfrew County, and the individual percentage in townships varies from practically nil to approximately 75.0. This is a large area of woodland and would, if managed under forestry principles, produce large quantities of forest products. Most of this woodland is accessible to markets and a large percentage of it is in small parcels. These facts make it possible to practise fairly intensive forestry. The intensity of practice in a forest depends on several factors:

(1) The location of a woodlot to available markets.

(2) The acreage under an individual ownership. A farmer with 15 acres of woodland may economically (if he is inclined) practise quite intensive forestry as his fuelwood requirements would utilize dead and diseased trees that should be taken out to improve his woodlot-on the other hand, a farmer with 25 acres or more of woodland would have to secure markets for these products.

(3) The percentage of woodland in an area. If there is a comparatively small percentage of woodland $(10 \%-20 \%)$ there is a ready market for fuelwood; while in an area where there is $50 \%-75 \%$ of woodland, there is no market for even the best fuelwood.

The condition of the woodlots in Ontario, as the result of past management or lack of management, varies considerably. Major-General Howard Kennedy made the statement in his 1947 report on Ontario woodlots that not more than 10 per cent could be classified as good forests. A large percentage of the remainder is scrub growth and is quite often composed of undesirable species of trees due to the tendency through the years to remove all the valuable species and leave the undesirable ones to seed up any openings. Recent watershed surveys have reported up to 75 per cent of the woodlots in some watersheds being pastured. This means, especially with the smaller woodlots of ten acres and less, that they will eventually disappear if the pasturing continues. All these woodlands would reproduce naturally if the owners could be persuaded to fence out the stock. There is in Ontario an exemption clause in the Assessment Act which states that an owner may secure exemption for his woodland up to 10 per cent of his holdings, with a maximum of 20 acres under a single ownership.

Major-General Kennedy also stated in his report that not more than two per cent of the woodlots in Ontario were managed wisely and well. The number of woodlots where the owner has done everything to make them high producing is almost nil. In comparison, there are thousands of farmers who do everything possible to improve their livestock and produce maximum field crops.

1 District Forester, Ontario Department of Lands and Forests, Hespeler, Ontario. 
The first step in woodlot education in Ontario was taken in 1895 when a Clerk of Forestry was appointed. Forestry reports were put out by him in 1897, 1903 and 1904, and for the most part covered interviews with farmers in the different parts of Southern Ontario and their opinions on the value of woodlots. These reports showed that there were many farmers who at that time valued their woodlots and were concerned about the clearing of entire farms for cultivation.

In 1905, E. J. Zavitz, who is now Chief of the Reforestation Division of the Ontario Department of Lands and Forests, was appointed Forester for Ontario. His first location was at the Ontario Agricultural College in Guelph, Ontario, and in addition to giving lectures on forestry to agricultural students, he commenced a forest nursery on the college grounds. A bulletin on the farm woodlot was written and published by him in 1907. This bulletin contained considerable information on reforestation by planting. Other editions of the bulletin on the farm woodlot were edited by A. H. Richardson, who headed the reforestation work in Ontario from 1921 until 1940. These were published in 1927, 1929 and 1933.

The present form of the farm woodlot bulletin was first published in 1939 and was written by the writer of this article. A revised edition was published in 1947. All these bulletins have had wide distribution and have probably helped a great deal in the education of woodlot owners as to the value and management of their woodlots.

Ontario has done extensive work on reforestation by planting since 1920 . In the early years, the tendency was to emphasize planting rather than the preservation and better management of the natural woodland. The general public and the foresters are also guilty of supporting the reforestation program much more readily than they have plans for the preservation and the management of natural woodland. There are several reasons for this, but perhaps the one that has the most influence is that it is more spectacular to change a waste area in a few years to an area covered with green trees than to fence woodlots from livestock which does not show-also, even if it is an improvement cutting, it appears destructive to the casual observer. Ontario has made considerable progress in the reforesting of waste land. There are now five large forest nurseries that are growing trees for free distribution to land owners and for planting on muncipal property. There are approximately 80,000 acres in county forests. Under the County Forest Scheme the land is purchased by the respective counties and it is looked after by the Ontario Department of Lands and Forests, under agreement, for 50 years. The general policy in the past has been for the counties to buy barren land which is much cheaper than land that is wooded, but today the counties are buying more natural woodland. It is estimated that approximately one-half of the county forests are natural woodland. It was quite noticeable also at conservation meetings during the period 1930-1940 that the emphasis was placed on reforestation; whereas at their meetings of today greater emphasis is being placed on the preservation of natural woodland and its better management.

The writer was assigned by the Ontario Department of Lands and Forests to do woodlot extension work in the Fall of 1929. It was evident, 


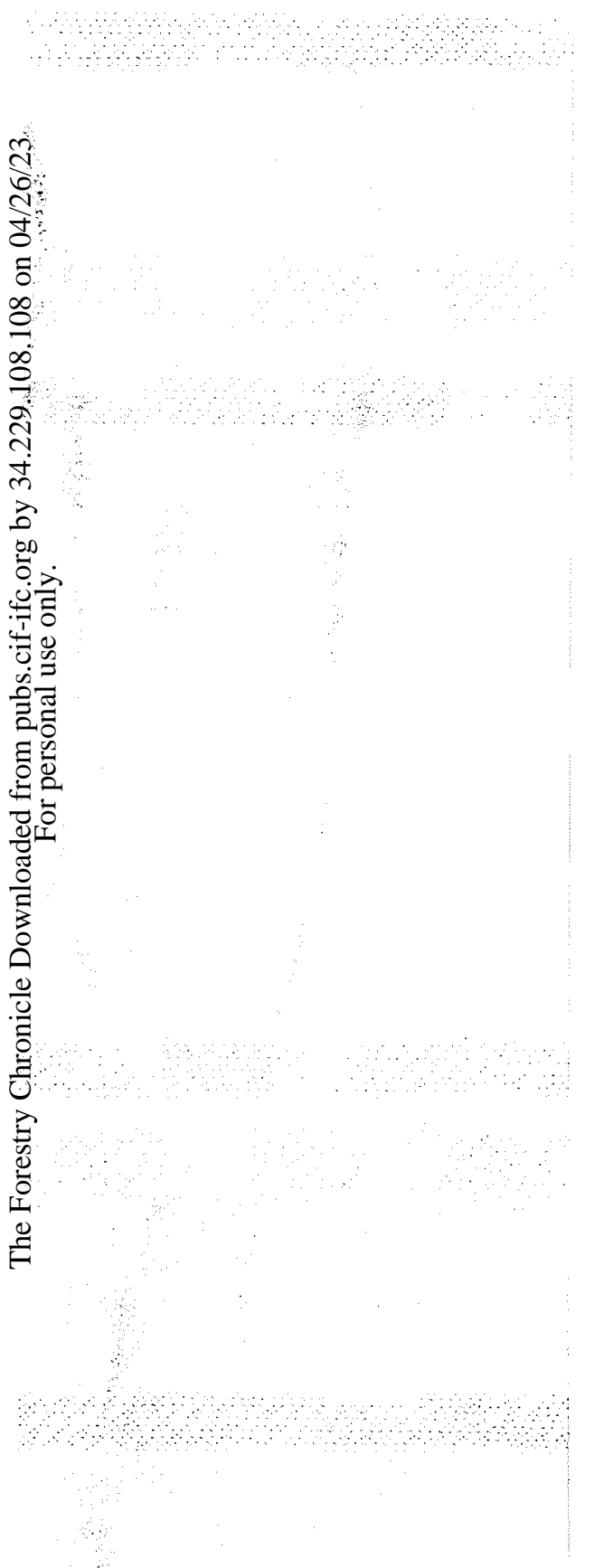

especially during the early years, that woodlot owners believed that a forester was only interested in reforestation by planting and, as a result, there were practically no requests for advice from private owners on the management of their woodlots.

The extension work consisted of writing articles for farmers' magazines and the daily and weekly newspapers. During the winter months lectures were given on forestry at county agricultural classes. School woodlot meetings were held when all the rural and village schools in a county were given an opportunity to tour a woodlot with a forester. In cases where well-managed woodlots were found along the highways and county roads, the owner was approached and permission asked for the Department of Lands and Forests to erect a sign bearing the words, "Demonstration Woodlot". These signs drew considerable attention and comment on the woodlot and had a part in making the public more woodlot conscious.

In 1941 the Ontario Department of Lands and Forests started the plan of establishing Zone Foresters. Previously, all the extension work in both the woodlot and reforestation was done by foresters whose headquarters were in the Parliament Buildings at Toronto. This meant that the forester had to drive hundreds of miles in some cases to make a call on a woodlot owner who had requested advice on woodlot management or reforestation, and a return visit was not often possible. Three foresters who had been previously stationed in Toronto were assigned to do the extension work and the administration of the county forests in a designated area. Each zone comprised about ten counties and a forestry office was opened in a central location. In addition, two forest tree nursery superintendents were assigned to do the extension work in the counties that were adjacent to their respective nurseries. The number of Zone Foresters has been increased through the years and there are now a total of twenty-three zone and assistant zone foresters doing extension work in the southern part of the Province of Ontario. There are also five District Foresters, one Regional Forester, seven foresters stationed at Forest Tree Nurseries, three foresters at the Seed Extracting Plant at Angus, Ontario, and five foresters at the Parliament Buildings in Toronto.

The more efficient management of woodlots has been very noticeable during the past twenty years. The public today realizes that a forester has a knowledge of proper woodlot management and there is an ever-increasing number of requests for advice on cutting and marketing of woodlot products. A zone forester will, on request, go over a woodlot with the owner. He will mark it for an improvement or timber cutting and will show the owner how to measure logs and give him information on how to market his woodlot products to the best advantage.

In 1950 a market survey was conducted by the zone foresters. A list of buyers was compiled which showed the species of trees they were interested in and the price paid for each species. Besides furnishing useful information that could be passed on to woodlot owners, this survey also gave the zone foresters a knowledge of available markets and the products manufactured. 
A very forward step was made to stop the slashing of woodlots in 1946 when an Act entitled, "The Trees Conservation Act" was passed by the Provincial Government. This Act gave a county the right to control cutting in woodlots where the products were to be sold. The zone foresters were agreeably surprised when a number of County Councils stated that they wished to pass a by-law to control cutting on privately-owned woodlots. At least twenty counties have passed a by-law to date. The by-laws are all based on a diameter limit, but the diameter limit is $10^{\prime \prime}-16^{\prime \prime}$ and is high enough to reduce in most cases the ruination of woodlots that are cut over. It is realized that a diameter limit is poor forestry, but it is much better than the alternative practice of selling woodlot products without any restrictions whatsoever. There has been very little opposition to the tree cutting by-law, and this can be accounted for by: (1) The public is educated to the need of conserving woodlots; (2) There was not the pressure to cut small material in the woodlots due to full employment in other industries.

The interest in woodlots is shown by the number of committees that have been appointed to investigate various phases of the woodlot. The Research Council of Ontario has an advisory committee headed by Dean J. W. B. Sisam of the Faculty of Forestry, University of Toronto, to recommend and study various phases of forestry. This committee was responsible for two surveys in the summer of 1951.

The taxation of woodland varies from township to township, and in some cases it is excessive due to the fact that the local assessor thinks that the value of the trees on the land should be considered when making up the assessment. A forestry student who is working on his Master's degree is spending the summer of 1951 investigating woodlot taxation in Ontario.

The Dominion Department of Agriculture and the Provincial Department of Agriculture are co-operating in an economic survey of the woodlot. About twenty-five farmers in ten different townships are contacted and questions asked in regard to the value they place on their woodlots and the financial returns secured in the past five years.

The woodlot situation in Ontario is far from satisfactory, but much progress has been made in the past twenty-five years. The next ten years should mark much further advance as woodlot owners are now realizing that their woodlots need attention and there are zone foresters available to give them technical advice. It is too bad that a large percentage are in a deplorable condition, and it will take several decades to convert them into fairly satisfactory woodlots. In most cases however, it is not as difficult as starting with bare land and reforesting. 